Article

\title{
On-Site Investigation of Airborne Bacteria and Fungi According to Type of Poultry Houses in South Korea
}

\author{
Sang-Joon Lee ${ }^{1}$ and Ki-Youn $\operatorname{Kim}^{1,2, *}$ \\ 1 Graduate School of Safety Engineering, Seoul National University of Science and Technology, \\ Seoul 01811, Korea; 1sj9897@naver.com \\ 2 Department of Safety Engineering, Seoul National University of Science and Technology, Seoul 01811, Korea \\ * Correspondence: kky5@seoultech.ac.kr; Tel.: +82-2-970-6376; Fax: +82-2-970-6377
}

Citation: Lee, S.-J.; Kim, K.-Y. On-Site Investigation of Airborne Bacteria and Fungi According to Type of Poultry Houses in South Korea. Processes 2021, 9, 1534. https:// doi.org/10.3390/pr9091534

Academic Editor: Jose C. Merchuk

Received: 24 June 2021

Accepted: 25 August 2021

Published: 28 August 2021

Publisher's Note: MDPI stays neutral with regard to jurisdictional claims in published maps and institutional affiliations.

Copyright: (c) 2021 by the authors. Licensee MDPI, Basel, Switzerland. This article is an open access article distributed under the terms and conditions of the Creative Commons Attribution (CC BY) license (https:// creativecommons.org/licenses/by/ $4.0 /)$.
Abstract: A field survey was conducted to quantify indoor exposure levels and emission rates of airborne microorganisms generated from domestic poultry buildings. There were three types of poultry buildings (caged layer house, broiler house, and layer house with manure belt), classified by the mode of manure treatment and ventilation, investigated in this study. Nine sites for each poultry building were selected and visited for measuring the exposure level and emission rate of airborne microorganisms. The total number of airborne bacteria and fungi among the airborne microorganisms were analysed based on the incubation method. Their emission rates were estimated by dividing the emission amount, which was calculated through multiplying indoor concentration $\left(\mathrm{cfu} / \mathrm{m}^{3}\right)$ by ventilation rate $\left(\mathrm{m}^{3} / \mathrm{h}\right)$, into the indoor area $\left(\mathrm{m}^{2}\right)$ and the number of poultries reared in the poultry building. The mean exposure levels of the total airborne bacteria and fungi in the poultry building were 7.92 (SD: 2.66) $\log \left(\mathrm{cfu} \mathrm{m}^{-3}\right)$ and 4.92 (SD: 1.79) $\log \left(\mathrm{cfu} \mathrm{m}^{-3}\right)$, respectively. Emission rates of airborne microorganisms in poultry buildings were estimated to be $0.263( \pm 0.088) \log \left(\mathrm{cfu} \mathrm{hen}^{-1} \mathrm{~h}^{-1}\right)$ and $0.839( \pm 0.371) \log \left(\mathrm{cfu} \mathrm{m}{ }^{-2} \mathrm{~h}^{-1}\right)$ for total airborne bacteria, and $0.066( \pm 0.031) \log \left(\mathrm{cfu} \mathrm{hen}^{-1} \mathrm{~h}^{-1}\right)$ and $0.617( \pm 0.235) \log \left(\mathrm{cfu} \mathrm{m}^{-2} \mathrm{~h}^{-1}\right)$ for total airborne fungi. The distribution patterns of the total airborne bacteria and fungi were similar regardless of poultry building type. Among poultry buildings, the broiler house showed the highest exposure level and emission rate of total airborne bacteria and fungi, followed by the layer house with manure belt and the caged layer house $(p<0.05)$. The finding that the broiler house showed the highest exposure level and emission rate of airborne microorganisms could be attributed to sawdust, which can be dispersed into the air by the movement of the poultry when it is utilized as bedding material. Thus, a work environmental management solution for optimally reducing airborne microorganism exposure is necessary for the broiler house.

Keywords: poultry house; airborne microorganism; bacteria; fungi; emission rate

\section{Introduction}

As a result of the global increase in demand for poultry food products, poultry production has changed dramatically in many industrialised and emerging countries over the past 50 years [1]. This trend is moving away from small traditional farms towards industrialised and specialised livestock facilities with increasing numbers of animals and high stock densities [2,3]. Furthermore, public anxiety is intensifying more than ever due to consumer distrust concerning the safety of poultry foodstuffs and the possibility of airborne infections being transmitted to humans.

Suspended microbes, such as airborne bacteria and fungi, are adsorbed into fine dust and reach the alveoli of chickens or workers through respiration, causing respiratory diseases such as pneumonia, asthma, bronchitis, and rhinitis [4,5]. Previous studies have reported that the concentrations of airborne biological contaminants in poultry houses is relatively higher than those of other indoor spaces, such as general industry and public buildings [6-8]. 
It is difficult to apply existing foreign data to the concentration and emission data of airborne microorganisms in poultry houses of South Korea due to differences in climate conditions and topography, various types of house operations, and the application of different measurement and analysis methods among countries [9-21]. Furthermore, emission factors related to airborne microorganisms also differ considerably depending on the animal species, the type of keeping, and as a result of different sampling conditions, collection methods, and methods for the determination of the concentrations [22-25]. Thus, fundamental information reflecting the various environmental conditions unique to South Korea is urgently required.

An objective of this study was to provide basic research data for the recommendation of a disease prevention plan for domestic farmers, exposed to airborne biological contaminants while breeding poultry, by evaluating the indoor concentrations and emission levels of airborne bacteria and fungi generated from poultry houses situated in South Korea.

\section{Materials and Methods}

\subsection{Subject}

The poultry houses of South Korea can be classified into three types, the caged layer house, the broiler house, and the layer house with faeces conveyor belts, based on the breeding purpose (i.e., meat or egg production), the manure treatment system, and the ventilation mode. The caged layer house, which keeps chickens within a limited space, is used for egg production. The broiler house is a cage in the form of a plastic house, where chickens are reared on the floor covered with bedding material, such as sawdust or chaff, for the purpose of producing meat. The layer house with a faeces conveyor belt is a modern house for producing eggs, which removes excreted manure by belt transport.

The investigation sites were randomly selected based on the operation type of the poultry houses, which were situated in nine provinces nationwide: Gyeonggi, Gangwon, Chungbuk, Chungnam, Kyungbuk, Gyeongnam, Jeonbuk, Jeonnam, and Jeju. The field survey was conducted in the spring (March to May), summer (June to August), autumn (September to November), and winter (December to February) of 2017 to reflect the seasonal conditions of South Korea. The site was visited for each poultry house. Table 1 presents the basic information of the poultry houses investigated in this study.

Table 1. Poultry house information surveyed in this study.

\begin{tabular}{|c|c|c|c|c|c|c|c|c|}
\hline \multirow[b]{2}{*}{ No. } & \multirow[b]{2}{*}{ Workplace Type } & \multirow[b]{2}{*}{ Manure Treatment } & \multicolumn{2}{|c|}{ Ventilation } & \multirow[b]{2}{*}{ Poultry Type } & \multirow{2}{*}{$\begin{array}{c}\text { Area } \\
\left(\mathrm{m}^{2}\right)\end{array}$} & \multirow{2}{*}{$\begin{array}{l}\text { No. of } \\
\text { Poultry }\end{array}$} & \multirow{2}{*}{$\begin{array}{c}\text { No. of } \\
\text { Workers }\end{array}$} \\
\hline & & & Mode & $\begin{array}{c}\text { Mean Rate } \\
\left(\mathrm{m}^{3} / \mathrm{h}\right)\end{array}$ & & & & \\
\hline 1 & \multirow[t]{9}{*}{ Caged layer house } & \multirow[t]{9}{*}{ Scraper } & \multirow[t]{9}{*}{ Forced ventilation } & 0.84 & \multirow[t]{9}{*}{ Layer } & 253 & 5060 & 2 \\
\hline 2 & & & & 1.26 & & 287 & 5244 & 2 \\
\hline 3 & & & & 1.09 & & 239 & 5167 & 2 \\
\hline 4 & & & & 0.77 & & 246 & 4934 & 3 \\
\hline 5 & & & & 1.57 & & 267 & 5528 & 2 \\
\hline 6 & & & & 1.08 & & 292 & 6420 & 2 \\
\hline 7 & & & & 1.43 & & 276 & 6517 & 2 \\
\hline 8 & & & & 1.68 & & 271 & 6923 & 3 \\
\hline 9 & & & & 1.21 & & 284 & 6389 & 2 \\
\hline 1 & \multirow[t]{9}{*}{ Broiler house } & \multirow{9}{*}{ Bedding material } & \multirow{9}{*}{ Natural ventilation } & 1.34 & \multirow[t]{9}{*}{ Broiler } & 125 & 2503 & 1 \\
\hline 2 & & & & 0.78 & & 107 & 2428 & 1 \\
\hline 3 & & & & 0.91 & & 132 & 2598 & 1 \\
\hline 4 & & & & 1.16 & & 148 & 2706 & 2 \\
\hline 5 & & & & 1.19 & & 153 & 2643 & 1 \\
\hline 6 & & & & 1.43 & & 161 & 2832 & 2 \\
\hline 7 & & & & 0.86 & & 171 & 2734 & 2 \\
\hline 8 & & & & 1.37 & & 113 & 2528 & 1 \\
\hline 9 & & & & 1.92 & & 128 & 2637 & 1 \\
\hline 1 & \multirow[t]{9}{*}{$\begin{array}{l}\text { Layer house with } \\
\text { manure belt }\end{array}$} & \multirow[t]{9}{*}{ Manure conveyor belt } & \multirow[t]{9}{*}{$\begin{array}{l}\text { Forced and natural } \\
\text { ventilation }\end{array}$} & 0.51 & \multirow[t]{9}{*}{ Layer } & 274 & 5853 & 2 \\
\hline 2 & & & & 1.24 & & 261 & 5921 & 3 \\
\hline 3 & & & & 0.73 & & 243 & 5506 & 3 \\
\hline 4 & & & & 1.06 & & 288 & 6238 & 3 \\
\hline 5 & & & & 0.69 & & 251 & 5846 & 2 \\
\hline 6 & & & & 1.31 & & 264 & 6108 & 2 \\
\hline 7 & & & & 0.89 & & 237 & 5347 & 3 \\
\hline 8 & & & & 1.35 & & 273 & 6784 & 2 \\
\hline 9 & & & & 1.07 & & 231 & 5724 & 2 \\
\hline
\end{tabular}




\subsection{Measurement}

The concentrations of airborne microorganisms in a poultry house were measured based on area sampling by setting a sampling point of $1 \mathrm{~m}$ above the centre of each site, and five replicates were taken at each poultry house. The air sampling was performed only during the daytime and the measurement time was between 2:00 and 3:00 p.m. The air samples were collected for $1 \mathrm{~min}$ using a one-stage viable particulate cascade impactor (Model 10-800, Andersen Inc, Bayport, MN, USA) set at a flow rate of 28.3 litres per minute. After sterilizing the inside of the cascade impactor with $70 \%$ alcohol prior to air sampling, a Trypticase soy agar (TSA) media, with $500 \mathrm{mg}$ of cycloheximide to suppress fungal growth, and a malt extract agar (MEA) media, with $100 \mathrm{mg}$ of chloramphenicol to suppress bacterial growth, were applied for incubating airborne bacteria and fungi, respectively. After air sampling, the culture medium plates were sealed with parafilm to prevent microbial contamination and immediately transported to the microbiology laboratory at $0-4{ }^{\circ} \mathrm{C}$ in an ice box. The TSA plates were kept in an incubator adjusted at $37.8^{\circ} \mathrm{C}$ for $1-2$ days. The MEA plates were incubated at room temperature for between 3 and 5 days. The counts for the air sample plates were corrected for multiple impaction using the positive hole conversion method [26] and they were reported in colony forming units per cubic metre of sampled air $\left(\mathrm{cfu} \mathrm{m}^{-3}\right)$.

\subsection{Estimation of Emission Factor}

The emissions of total airborne bacteria and fungi were calculated by multiplying their mean indoor concentrations, which were measured $1 \mathrm{~m}$ above the centre of the floor of the poultry building, by the mean ventilation rate. The air flow rate was measured by multiplying the area of all the exhaust fans by an average air flow velocity, in the case of a forced ventilation system, and was estimated by applying the thermal equilibrium method based on the temperature difference between inside and outside the poultry building, in the case of natural ventilation system. The total housing area of each poultry building and the total weight of the chickens were determined to estimate the emission factors. The area was measured with a tapeline or by the responsible farmer in cases where measurement was not allowed due to concerns about the spread of pathogenic airborne infection. It was impossible to measure the total weight of the chickens, thus, we estimated the total weight after setting $1.5 \mathrm{~kg}$ as the weight of one chicken and after receiving the breeding data from the responsible farmer. The reason for setting the weight of one chicken to $1.5 \mathrm{~kg}$ was based on the standard value suggested in the animal unit (AU) concept. On the basis of this information, the emission factors of total airborne bacteria and fungi were estimated by the unit heads (No.) and the unit area $\left(\mathrm{m}^{2}\right)$. The calculation applied here is the same as Formula (1) and (2).

Enclosed poultry building with forced ventilation system:

Emission amount $\left(\log (\mathrm{cfu}) \mathrm{h}^{-1}\right)=$ Indoor concentration $\left(\log (\mathrm{cfu}) \mathrm{m}^{-3}\right) \times$ ventilation rate $\left(\mathrm{m}^{3} \mathrm{~h}^{-1}\right)$
Emission factor $\left(\log (\mathrm{cfu}) \mathrm{m}^{-2} \mathrm{~h}^{-1}\right.$ or $\log (\mathrm{cfu})$ head $\left.{ }^{-1} \mathrm{~h}^{-1}\right)=$ Emission amount $\left(\log (\mathrm{cfu}) \mathrm{h}^{-1}\right) \div$ Area $\left(\mathrm{m}^{2}\right)$ or Head $($ No. $)$

Open poultry building with natural ventilation system:

Emission amount $\left(\log (\mathrm{cfu}) \mathrm{h}^{-1}\right)=$ Indoor concentration $\left(\log (\mathrm{cfu}) \mathrm{m}^{-3}\right) \times$ Air transfer rate $\left(\mathrm{m} \mathrm{h}^{-1}\right) \times$ Area $\left(\mathrm{m}^{2}\right)$ Emission factor $\left(\log (\mathrm{cfu}) \mathrm{m}^{-2} \mathrm{~h}^{-1}\right.$ or $\log (\mathrm{cfu})$ head $\left.^{-1} \mathrm{~h}^{-1}\right)=$ Emission amount $\left(\log (\mathrm{cfu}) \mathrm{h}^{-1}\right) \div$ Area $\left(\mathrm{m}^{2}\right)$ or Head (No.)

where Air transfer rate $\left(\mathrm{m} \mathrm{h}^{-1}\right)=1.44 \times 10^{-4} \mathrm{~m} / \mathrm{sec}$ : based on mass transfer theory by Cussler [27].

\subsection{Data analysis}

The geometric mean (GM), geometric standard deviation (GSD), and range were calculated after performing normal distribution verification on the field measurement data. The ANOVA and Duncan's multiple comparative analysis, using the SAS package program, 
demonstrated the statistical differences in indoor concentrations and emission factors of airborne bacteria and fungi according to the type of poultry building.

\section{Results and Discussion}

\subsection{Indoor Concentration Distribution Pattern of Airborne Bacteria and Fungi}

As indicated in Figure 1, the indoor concentrations of airborne bacteria and fungi by poultry building type were shown as a logarithmic normal distribution and are represented as the geometric mean and geometric standard deviation. In the case of total airborne bacteria, the mean level for the caged layer house, broiler house, and layer house with manure belt were 7.56 (GSD: 2.08) $\log (\mathrm{cfu}) \mathrm{m}^{-3}, 8.26$ (GSD: 3.01) $\log (\mathrm{cfu}) \mathrm{m}^{-3}$, and 7.93 (GSD: 2.89) $\log (\mathrm{cfu}) \mathrm{m}^{-3}$, respectively. Meanwhile, the mean levels of airborne fungi were 4.09 (GSD: $2.03 \log (\mathrm{cfu}) \mathrm{m}^{-3}$ for the caged layer house, 5.56 (GSD:1.73) $\log$ (cfu) $\mathrm{m}^{-3}$ for the broiler house, and 5.12 (GSD:1.61) $\log (\mathrm{cfu}) \mathrm{m}^{-3}$ for the layer house with manure belt. Regardless of the type of poultry building, the mean concentrations of airborne bacteria and fungi were determined to be 7.92 (GSD: 2.66) $\log$ (cfu) $\mathrm{m}^{-3}$ and 4.92 (GSD: 1.79) $\log (\mathrm{cfu}) \mathrm{m}^{-3}$, respectively. The concentration distribution pattern of total airborne bacteria and fungi was similar, and those levels were shown in the following order: broiler house $>$ layer house with manure belt $>$ caged layer house $(p<0.05)$. The indoor concentration of airborne bacteria and fungi in the broiler house building type was relatively high compared to the other poultry building types because the broilers are raised by laying sawdust on the floor. Thus, the particles generated from the sawdust used as bedding material and the dried manure, which contains microorganisms, were scattered in the air during the chickens' movements.

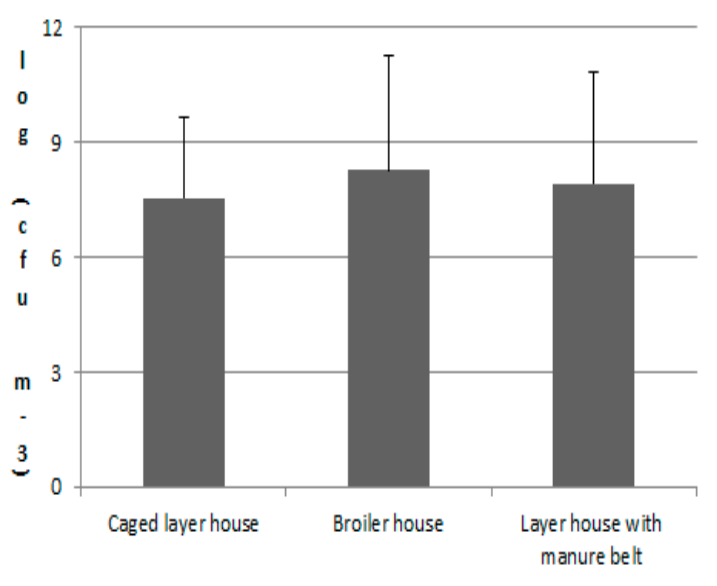

(a) Total airborne bacteria

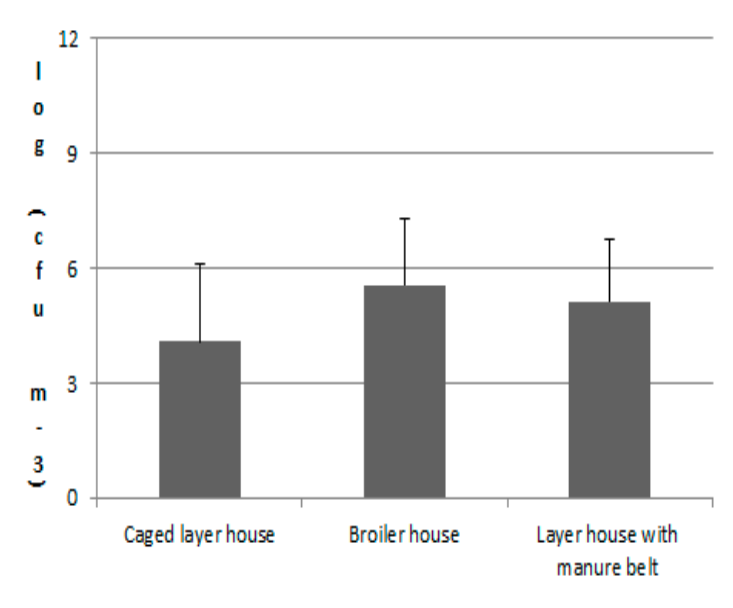

(b) Total airborne fungi

Figure 1. Mean concentration of total airborne microorganisms in poultry buildings.

The previous foreign data [9-21] on the field concentrations of total airborne bacteria and fungi among biological contaminants in poultry buildings are as follows. The mean concentrations of airborne bacteria and fungi in poultry houses were approximated to be $7 \times 10^{5} \mathrm{CFU} / \mathrm{m}^{3}$ and $6 \times 10^{3} \mathrm{CFU} / \mathrm{m}^{3}$, respectively. The range is relatively high, likely as a result of the different housing types. The mean concentrations of total bacteria were slightly higher in laying hens, at $1 \times 10^{6} \mathrm{CFU} / \mathrm{m}^{3}$, as compared to broilers, at $6 \times 10^{5} \mathrm{CFU} / \mathrm{m}^{3}$. In contrast, the mean mould concentrations were slightly higher in broilers, at $1 \times 10^{4} \mathrm{CFU} / \mathrm{m}^{3}$, compared with laying hens, at $3 \times 10^{3} \mathrm{CFU} / \mathrm{m}^{3}$. Based on the foreign literature review, the majority of the poultry buildings surveyed were of the broiler house type and, of particular note, was the fact that all the previous studies were performed in Germany and the USA. Furthermore, the variation in measured data among the researchers was found to be quite large, a trend that was similar in this study. This is presumed to be the result of the different indoor and outdoor environmental conditions 
at the time of the field measurements, the structure of the poultry building and chicken breeding density, and the measuring equipment used to collect airborne microorganisms.

\subsection{Distribution Pattern of Emission Factor of Airborne Bacteria and Fungi}

Figure 2 shows the mean emission factor of airborne bacteria and fungi by type of poultry building. In the case of total airborne bacteria, the mean emission factor for the caged layer house, the broiler house, and the layer house with manure belt were $0.189( \pm 0.069) \log (\mathrm{cfu}) \mathrm{hen}^{-1} \mathrm{~h}^{-1}$ and $0.727( \pm 0.388) \log (\mathrm{cfu}) \mathrm{m}^{-2} \mathrm{~h}^{-1}, 0.386( \pm 0.116) \log (\mathrm{cfu}) \mathrm{hen}^{-1} \mathrm{~h}^{-1}$ and $1.026( \pm 0.408)$ $\log (\mathrm{cfu}) \mathrm{m}^{-2} \mathrm{~h}^{-1}$, and 7.93(GSD:2.89) $\log (\mathrm{cfu}) \mathrm{m}^{-3}$, respectively. The mean emission factors of airborne fungi were $0.052( \pm 0.027) \log (\mathrm{cfu}) \mathrm{hen}^{-1} \mathrm{~h}^{-1}$ and $0.504( \pm 0.189) \log (\mathrm{cfu}) \mathrm{m}^{-2} \mathrm{~h}^{-1}$ for caged layer houses, $0.084( \pm 0.039) \log (\mathrm{cfu}) \mathrm{hen}^{-1} \mathrm{~h}^{-1}$ and $0.726( \pm 0.214) \log (\mathrm{cfu}) \mathrm{m}^{-2} \mathrm{~h}^{-1}$ for broiler houses, and $0.061( \pm 0.026) \log (\mathrm{cfu}) \mathrm{hen}^{-1} \mathrm{~h}^{-1}$ and $0.620( \pm 0.301) \log (\mathrm{cfu}) \mathrm{m}^{-2} \mathrm{~h}^{-1}$ for layer houses with manure belt. The mean emission factors, regardless of the type of poultry building, were $0.263( \pm 0.088) \log (\mathrm{cfu}) \mathrm{hen}^{-1} \mathrm{~h}^{-1}$ and $0.839( \pm 0.371) \log (\mathrm{cfu}) \mathrm{m}^{-2} \mathrm{~h}^{-1}$ for airborne bacteria and $0.066( \pm 0.031) \log (\mathrm{cfu}) \mathrm{hen}^{-1} \mathrm{~h}^{-1}$ and $0.617( \pm 0.235) \log (\mathrm{cfu}) \mathrm{m}^{-2} \mathrm{~h}^{-1}$ for airborne fungi. Based on the results obtained from this study, the distribution pattern of the emission factor for total airborne bacteria and fungi was similar, and the level of emission factor was shown in the following order: broiler house > layer house with manure belt $>$ caged layer house $(p<0.05)$. This difference in the emission factor by type of poultry building would be the variation in the concentration level of airborne microorganisms and the ventilation rates applied to the poultry building at the time of measurement.

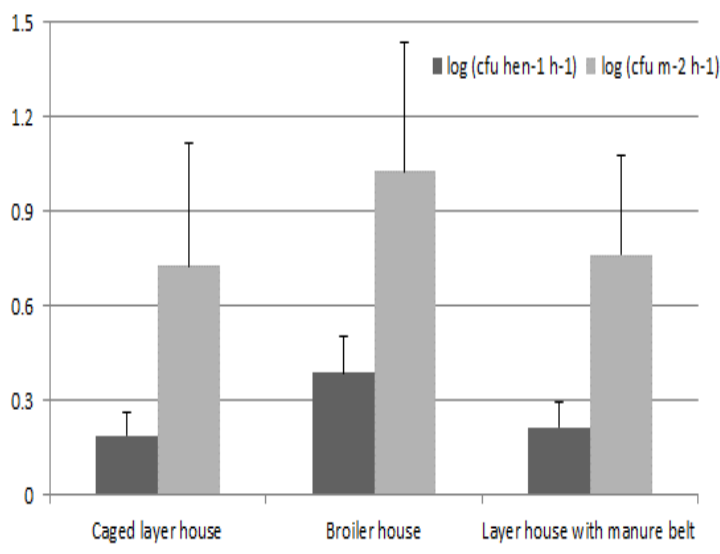

(a) Total airborne bacteria

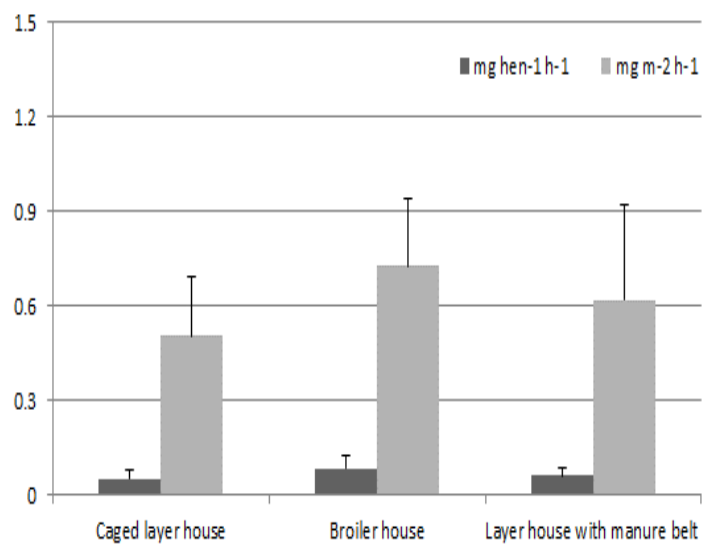

(b) Total airborne fungi

Figure 2. Mean emission rates of total airborne microorganisms in poultry buildings.

According to the previous data relating to emission factors of airborne bacteria and fungi for poultry houses, their ranges were $1 \times 10^{3}-5.9 \times 10^{6} \mathrm{CFU} / \mathrm{LU} \times \mathrm{s}$ and $2 \times 10^{1}-5.6 \times 10^{4} \mathrm{CFU} / \mathrm{LU} \times \mathrm{s}$, respectively [22-25]. The livestock unit (LU) for the standardisation of measurement values and various air sampling equipment, such as impinger, filter, and impactor, were applied to this data. Therefore, the objective comparative evaluation of emission factors of total airborne bacteria and fungi in South Korean poultry houses, which were estimated in this study, is difficult, at present, due to the application of different emission factor units and the utilization of different air sampling collectors.

\subsection{Limitations of This Study}

It is necessary to interpret this measurement data by considering that the representative concentration is assumed for the concentration measured at one point in each poultry building, and that both the forced and natural ventilation systems are assumed to have equal ventilation effects in all the poultry buildings. 
Likewise, the Andersen sampler used for this investigation has some limitations. First, the sampling time of $1 \mathrm{~min}$ is not really representative. Second, it should be mentioned that, with the Andersen sampler, only the number of particles carrying microorganisms can be determined and not all microorganisms in the respective particle size fraction. Regardless of the total number of cultivatable bacteria on an impacted particle, only one macroscopically visible colony on the nutrient agar per such particle is determined. This is especially problematic in poultry houses where particles containing thousands of single bacteria were found, which greatly underestimates the real concentrations in comparison to sampling in a liquid, e.g., by impingement or wet cyclone.

\section{Conclusions}

The distribution patterns of total airborne bacteria and fungi were similar regardless of poultry building type. Among poultry buildings, the broiler house showed the highest exposure level and emission rate of total airborne bacteria and fungi, followed by layer house with manure belt, and caged layer house. That the broiler house showed the highest exposure level and emission rate of airborne microorganism can be attributed to sawdust, which is utilized as bedding material and can be dispersed into the air by the movement of the chickens. Thus, based on the finding that the bedding materials, such as sawdust and rice-hull contaminated with faeces, is kicked up by chicken movement, thereby reaerosolising the bacteria and fungi, the pertinent work environmental management solution for reducing airborne microorganism exposure should, optimally, be devised according to the characteristics of the poultry house.

Author Contributions: Conceptualization, K.-Y.K.; methodology, K.-Y.K.; formal analysis, K.-Y.K.; investigation, S.J.L.; data curation, S.-J.L.; writing—original draft preparation, S.-J.L.; writingreview and editing, K.-Y.K.; funding acquisition, K.-Y.K. All authors have read and agreed to the published version of the manuscript.

Funding: This research was funded by the Ministry of Agriculture, Food and Rural Affairs (MAFRA) (grant number: 319115-02-2-SB010).

Acknowledgments: This work was supported by the Korea Institute of Planning and Evaluation for Technology in Food, Agriculture and Forestry (IPET) through the Agri-Bio Industry Technology Development Program, funded by the Ministry of Agriculture, Food and Rural Affairs (MAFRA) (grant number: 319115-02-2-SB010).

Conflicts of Interest: The authors declare no conflict of interest.

\section{References}

1. Clauß, M. Emission of Bioaerosols from Livestock Facilities: Methods and Results from Available Bioaerosol Investigations in and Around Agricultural Livestock Farming; Thünen Working Paper No. 138a; EconStor: Berlin, Germany, 2020.

2. Ko, G.; Simmons, O.D.; Likirdopulos, C.A.; Worley-Davis, L.; Williams, C.M.; Sobsey, M.D. Endotoxin levels at Swine farms using different waste treatment and management technologies. Environ. Sci. Technol. 2010, 44, 3442-3448. [CrossRef] [PubMed]

3. Millner, P.D. Bioaerosols associated with animal production operations. Biores. Technol. 2009, 100, 5379-5385. [CrossRef] [PubMed]

4. Du, L.; Yang, L.; Yang, C.; Dominy, R.; Hu, C.; Du, H.; Li, Q.; Yu, C.; Xie, L.; Jiang, X. Investigation of bio-aerosol dispersion in a tunnel-ventilated poultry house. Comput. Electron. Agric. 2019, 167, 1-12. [CrossRef]

5. Sowiak, M.; Brodka, K.; Kozajda, A.; Buczynska, A.; Szadkowska-Stanczyk, I. Fungal aerosol in the process of poultry breedingQuantitative and qualitative analysis. Med. Pracy. 2012, 63, 1-10.

6. Plewa, K.; Lonc, E. Analysis of airborne contamination with bacteria and moulds in poultry farming: A case study. Pol. J. Environ. Stud. 2011, 20, 725-731.

7. Nonnenmann, M.W.; Bextine, B.; Dowd, S.E.; Gimore, K.; Levin, J.L. Culture-independent characterization of bacteria and fungi in a poultry bioaerosol using pyrosequencing: A new approach. J. Occup. Environ. Hyg. 2010, 7, 693-699. [CrossRef]

8. Venter, P.; Lues, J.F.R.; Theron, H. Quantification of bioaerosols in automated chicken egg production plants. Poult. Sci. 2004, 83, 1226-1231. [CrossRef] [PubMed]

9. Brooks, J.P.; McLaughlin, M.R.; Scheffler, B.; Miles, D.M. Microbial and antibiotic resistant constituents associated with biological aerosols and poultry litter within a commercial poultry house. Sci. Total Environ. 2010, 408, 4770-4777. [CrossRef] [PubMed]

10. Chai, T.J.; Zhang, J.X.; Hou, Y.P.; Zhao, Y.L. Spread of microorganism aerosol in animal house to its environments. Anim. Husb. Vet. Med. 2001, 33, 10-12. 
11. Schulz, J.; Hartung, J.; Seedorf, J.; Formosa, L.C. Staphylococci as an indicator for bacterial emissions from broiler houses. Proc. Interim Congr. Int. Soc. Anim. Hyg. 2004, 1, 75-77.

12. Witkowska, D.; Sowińska, J. The effectiveness of peppermint and thyme essential oil mist in reducing bacterial contamination in broiler houses. Poult. Sci. 2013, 92, 2834-2843. [CrossRef] [PubMed]

13. Saleh, M. Untersuchungen zur Luftqualität in Verschiedenen Systemen der Geflügelhaltung Mit Besonderer Berücksichtigung von Staub und Luftkeimen. Ph.D. Dissertation, Tierärztliche Hochschule Hannover, Hanover, Germany, 2006. (In German).

14. Agabou, A. Air-borne bacterial contaminations in two broiler hatcheries in the North-East of Algeria. Vet. World 2009, 2, 49-50.

15. Angersbach-Hegers, S. Untersuchungen zur Emission und Verfrachtung luftgetragener Mikroorganismen von der Auslauffläche Einer Legehennenfreilandhaltung. Ph.D. Dissertation, Tierärztliche Hochschule Hannover, Hanover, Germany, 2002. (In German).

16. Blomberg, S.; Winter, Ö.; Hinz, H.R. Abschlussbericht Projekt 05HS012/1-2 Beurteilung Verschiedener Haltungssysteme für Legehennen aus Sicht des Arbeits- und Umweltschutzes: Belastungen Durch Luftgetragene Stäube und Mikroorganismen. 2009. (In German). Available online: https:/ / service.ble.de/ptdb /index2.php?detail_id=89153\&site_key=145\&zeilenzahl_zaehler=59 2\&NextRow $=70 \& p I d=89153 \& d I d=110820$ (accessed on 24 June 2021).

17. Springorum, A.C.; Clauß, M.; Rieger, M.; Hinz, T.; Hartung, J. Mikrobielle Belastung der Luft in verschiedenen alternativen Haltungsformen für Legehennen. Gefahrstoffe. Reinhalt. Der Luft 2015, 75, 331-335. (In German)

18. Popescu, S.; Borda, C.; Diugan, E. Microbiological Air Contamination in Different Types of Housing Systems for Laying Hens. Pro. Environ. 2013, 6, 549-555.

19. Popescu, S.; Borda, C.; Hegedus, C.I.; Stefan, R.; Lazar, E.A. The Microbiologic Quality of the Air in Broiler Houses. Anim. Sci. Biotechnol. 2010, 43, 119-123.

20. Hähnchenmastanlagen-Aktuelle Messergebnisse und vergleichende Untersuchungen von drei verschiedenen Ställen. Gefahrst.Reinhalt. der Luft 2011, 71, 362-366. (In German)

21. Gärtner, A.; Gessner, A.; Geueke, K.J.; Knust, S. Emissionen aus Hähnchenmastanlagen. Untersuchung des Bioaerosolanteils in den Partikelfraktionen PM2.5 und PM10. Gefahrst.-Reinhalt. Der Luft. 2017, 77, 249-256. (In German)

22. Gärtner, A.; Gessner, A.; Jäckel, U. Ermittlung von Mikroorganismen-Emissionen einer Hähnchenmastanlage. Gefahrst.-Reinhalt. Der Luft. 2009, 69, 359-362. (In German)

23. Seedorf, J. An emission inventory of livestock-related bioaerosols for Lower Saxony, Germany. Atmos. Environ. 2004, 38, 6565-6581. [CrossRef]

24. Zhao, Y.; Zhao, D.; Ma, H.; Liu, K.; Atilgan, A.; Xin, H. Environmental assessment of three egg production systems-Part III: Airborne bacteria concentrations and emissions. Poult. Sci. 2016, 95, 1473-1481. [CrossRef]

25. Lippmann, J.; Mietke-Hofmann, H.; Deichmann, J.; Heidenreich, T. Bestimmung und Beurteilung wichtiger Bestandteile des Bioaerosols in der Stall- und Abluft sowie im Stallumfeld (Luv/Lee) zur Bereitstellung von Kenndaten und Bewertung des Emissions- und Immissionsverhaltens mikrobieller Luftbestandteile aus Tierställen (Geflügel). In Schriftenreihe des LfULG, Heft 13; Sächsisches Landesamt für Umwelt, Landwirtschaft und Geologie: Dresden, Germany, 2016. (In German)

26. Macher, J.M. Positive-hole correction for multiple-jet impactors for collecting viable microorganisms. Am. Ind. Hyg. Assoc. J. 1989, 50, 561-568. [CrossRef] [PubMed]

27. Cussler, E.L. Diffusion: Mass Transfer in Fluid Systems; Cambridge University Press: Cambridge, UK, 1984. 